\title{
Benthic animal contribution to cellulose breakdown in sediments of mangrove estuaries in the southwestern islands of Japan
}

\author{
Kyohei Yamada $^{1}$, Shingo Maegawa ${ }^{2} \&$ Haruhiko Toyohara ${ }^{1, *}$ \\ ${ }^{1}$ Division of Applied Biosciences, Graduate School of Agriculture, Kyoto University, Kyoto 606-8502, Japan \\ ${ }^{2}$ Graduate School of Informatics, Department of Intelligence Science and Technology, Kyoto University, Kyoto 606-8501, \\ Japan
}

Received 29 December 2012; Accepted 20 May 2013

\begin{abstract}
To determine the process of cellulose degradation in mangrove estuaries of the South-Western Islands, Japan, the cellulase activity of sediments was examined at a total of 9 sites on Okinawa Main Island (the River Gesashi and Manko), Ishigaki Island (Nagura Gulf and River Miyara), and Iriomote Island (rivers Urauchi, Mare, Hinai, Shira and Maira). Zymographic analysis was used to record cellulase activity in all sediment samples and in the meiobenthos. A 27-kDa cellulase activity band was expressed by several animal groups examined in the meiobenthos, including Gammaridea, Turbellaria, Ostracoda, Oligochaeta, Nematoda, and Polychaeta. However, the mangrove whelk, Terebralia palustris, which is a widely distributed member of the macrobenthos in these areas except Okinawa Main Island, expressed cellulase activities at 29, 31, 49, and $56 \mathrm{kDa}$. Interestingly, 31-kDa cellulase activity levels were recorded both in sediments and in the feces of T. palustris. The results of this study indicate that various benthic animals contribute to cellulose degradation in mangrove sediments of estuaries in the Southwestern Japanese Islands.
\end{abstract}

Key words: benthos, cellulase, estuary, mangrove, South-Western Islands

\section{Introduction}

Mangroves represent unique ecological systems that exhibit extraordinarily high biological productivity. This is because the roots of mangrove trees function as refuges for larval fish, while mangrove litter is utilized as a carbon source for many estuarine organisms (Chong 2007). In Japan, mangrove estuaries are primarily located in the Southwestern Islands of Okinawa Prefecture and Amami Island in Kagoshima Prefecture; however, they can grow as far north as the River Aono $\left(34^{\circ} 38^{\prime} \mathrm{N}\right)$ in Shizuoka Prefecture (Takeshita \& Noguchi 1974). Vast areas of pristine mangrove estuaries are found on Iriomote Island, which is one of the southwestern islands of Okinawa Prefecture. Kandelia obovata, Bruguiera gymnorhiza, Rhizophora stylosa, Avicennia marina, Sonneratia alba. Rhizophora stylosa are the main species of mangrove tree growing there, restricted to islands south of Okinawa Main Island. Avicen-

\footnotetext{
* Corresponding author: Haruhiko Toyohara; E-mail, toyohara@kais. kyoto-u.ac.jp
}

nia marina grows in localized areas on islands south from Miyako Island, and Sonneratia alba grows only Iriomote Island (Wakushima et al. 1994). Despite extensive efforts to construct and validate the food chain for mangrove estuaries using stable isotopic and fatty acid analyses (Chong 2007, Loneragan et al. 1997, Meziane et al. 2000, Chong et al. 2001, Bouillon et al. 2004, Bachok et al. 2003, Bouillon et al. 2008), the process of cellulose degradation in the mangrove ecosystem remains unknown.

Cellulose is an essential component of plant cell walls, and is a major organic material in wetland sediments. It is a high-molecular-weight polysaccharide composed of $\beta$-1,4-linked glucose residues and is biochemically stable compared to starch, in which glucose residues are bound by $\alpha-1,4$ and $\alpha-1,6$ linkages (Cosgrove 2005, Vries \& Visser 2001).

Cellulase is a general term used for enzymes that belong to the glycoside hydrolase family (Tanimura et al. 2013). This group of enzymes catalyzes the hydrolysis of the $\beta$-1,4-glycoside linkages of cellulose chains and includes endo- $\beta$-1,4-glucanase (EC 3.2.1.4) and cellobiohydrolase 
(EC 3.2.1.91). Cellulose is degraded to glucose by these enzymes via two steps. In the first step, endo- $\beta$-1,4-glucanase and cellobiohydrolase degrade cellulose to cellulodextrin or cellobiose. In the second step, another enzyme, $\beta$-glucosidase (EC 3.2.1.21), further degrades the molecules into glucose (Watanabe \& Tokuda 2010). Cellulases from bacteria (Olson et al. 2010), filamentous fungi (Trinci et al. 1994), basidiomycetes (Chow et al. 1994), myxomycetes (Ronsness 1968), and protozoa (Bera-Maillet et al. 2005) have been extensively studied. Furthermore, cellulase genes have been identified in termites (Watanabe et al. 1998) and nematodes (Smant et al. 1998, Kikuchi et al. 2005). The presence of such endogenous cellulases has also been reported in aquatic animals, such as the blue mussel (Xu et al. 2001), abalone (Suzuki et al. 2003), sea urchin (Nishida et al. 2007), and a brackish water clam (Sakamoto et al. 2007).

Occurrence of cellulase activities of Telescopium telescopium was reported by Alexander et al. (1979), who detected activity of laminarinase, fucoidanase, amilase, cellulase, xylanase, $\beta$-glucosidase and $\beta$-galactosidase in liquid extracts of the crystalline style. Cellulase activity was also found in the mangrove whelk Terebralia palustris, a species related to Telescopium telescopium distributed in the mangrove estuaries of Iriomote Island (Niiyama \& Toyohara, 2011); and has also been found in the blood cockle Anadara granosa, estuarine mysids (Mesopodopsis tenuipes, M. orientalis, Notacanthomysis hodgarti, Acanthomysis thailandica, Rhopalophthalmus orientalis, and $R$. egregius) and Acetes shrimps (Acetes sibogae, A. japonicus, and A. indicus) collected from Matang Mangrove in Malaysia (Niiyama, Hanamura et al., 2012, Niiyama, Toyohara \& Tanaka, 2012). These findings suggest the presence of a significant contribution of macrobenthos towards the degradation of cellulose in mangrove estuaries.

The meiobenthos (animals able to pass through a 1-mmmesh sieve) includes a wide range of fauna: at least 22 phyla (Robert \& Hjalmar 1988). Toyohara et al. (2012) first reported the possibility that the meiobenthos (including Turbellaria, Nematoda, and Oligochaeta) contributes to cellulose degradation in wetlands. Subsequently, Yamada and Toyohara (2012) reported the importance of the meiobenthos (including Oligochaeta and Ostracoda) for cellulose degradation in a Hokkaido wetland. Alongi surveyed the distribution of meiobenthos in Missionary Bay, Hinchinrook Island (on the northeastern coast of Australia) and found that meiofaunal densities were highest in Austral autumn and winter and lowest in Austral spring and summer. (Alongi 1987). However, the function of the meiobenthos in the cellulose degradation of mangrove estuaries remains unresolved.

In the present study, cellulose activity in several mangrove estuaries in the southwestern islands of Japan to determine the process of cellulose degradation and understand how benthic animals contribute to this process. The results indicate that various benthic animals are involved in cellulose degradation of these mangrove estuary sediments.

\section{Materials and Methods}

\section{Materials}

Sampling was performed from December 15 to 18, 2010, at nine sampling sites (Fig. 1): Okinawa main island (2 sites), Ishigaki Island (2 sites), and Iriomote Island (5 sites). Sediments were from nine mangrove estuaries (of the rivers Gesashi, $26^{\circ} 36^{\prime} \mathrm{N} 128^{\circ} 8^{\prime} \mathrm{E}$; Manko, $26^{\circ} 11^{\prime} \mathrm{N} 127^{\circ} 40^{\prime} \mathrm{E}$; Miyara, $24^{\circ} 21^{\prime} \mathrm{N} 124^{\circ} 12^{\prime} \mathrm{E}$; Urauchi, $24^{\circ} 25^{\prime} \mathrm{N} 123^{\circ} 46^{\prime} \mathrm{E}$; Mare, $24^{\circ} 25^{\prime} \mathrm{N} 123^{\circ} 46^{\prime} \mathrm{E}$; Hinai, $123^{\circ} 81^{\prime} \mathrm{N} 24^{\circ} 39^{\prime} \mathrm{E}$; Shira, $24^{\circ} 19^{\prime} \mathrm{N} 123^{\circ} 54^{\prime} \mathrm{E}$; Maira; $24^{\circ} 18^{\prime} \mathrm{N} 123^{\circ} 54^{\prime} \mathrm{E}$; and Nagura Gulf, $24^{\circ} 26^{\prime} \mathrm{N} 124^{\circ} 6^{\prime} \mathrm{E}$ : co-ordinates recorded with an eTrex Vista HCx hand-held GPS unit from Garmin, Olathe, Kansas, USA). Tablel shows the dominant species of mangrove at each site.

On November 22, 2011, additional sediment samples were collected from the Mare and Hinai rivers. A further five T. palustris specimens were collected from the Mare river during the second period of sampling to assess the mechanism of cellulose degradation more precisely. At each sampling site, approximately $1 \mathrm{~kg}$ of sediment was collected from a depth of $5 \mathrm{~cm}$, selecting a single sampling point devoid of plants. Fallen leaves of Rhizophora stylosa were collected at the Mare river. The collected sediment and fallen leaves samples were then transported at $4^{\circ} \mathrm{C}$ to the laboratory at Kyoto University and stored at $4{ }^{\circ} \mathrm{C}$ until analysis.

Two of the five live T. palustris transported to the laboratory in Kyoto were dissected to remove the midgut, which was then homogenized with three volumes of cold phosphate-buffered saline (PBS, containing $140 \mathrm{mM} \mathrm{NaCl}$, $2.7 \mathrm{mM} \mathrm{KCl}, 8 \mathrm{mM} \mathrm{Na}_{2} \mathrm{HPO}_{4}$, and $1.5 \mathrm{mM} \mathrm{KH}_{2} \mathrm{PO}_{4}, \mathrm{pH}$ 7.4). The protein concentrations of the extracts were measured according to the method of Bradford (1976), using bovine serum albumin as the standard. The protein concentration of the extracts were then adjusted to $1 \mathrm{mg} / \mathrm{mL}$ and stored at $-20^{\circ} \mathrm{C}$ until use. The other three T. palustris were kept alive at room temperature in the laboratory (approximately $20^{\circ} \mathrm{C}$ ), to collect the feces for cellulase analysis. Unless otherwise specified, chemicals used were special reagent grade (Nacalai Tesque Inc.; Kyoto, Japan).

\section{Isolation of meiobenthos}

Live meiobenthic organisms were isolated from the sediments within 1 week of collection by recovery from the fraction small enough to pass through a 1-mm-mesh sieve, but too large to pass through one of $63-\mu \mathrm{m}$. Individual animals were isolated under a microscope (S2X12; Olympus, Tokyo, Japan). Organisms were identified to at least the Class level, according to Robert et al. (1988), except for nematodes. Arthropods were classified according to Joei \& Gorge (2001). We used single individuals of each animal 


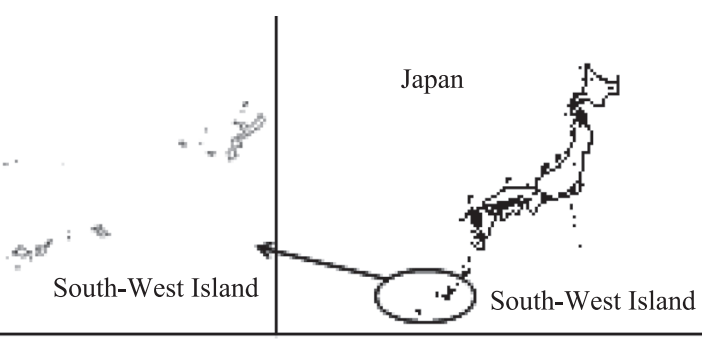

- Mangrove estuary

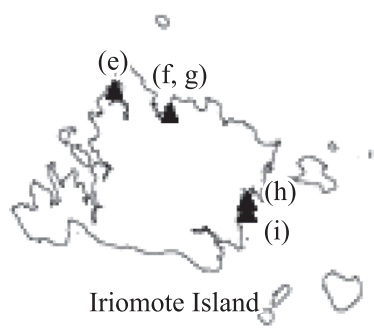

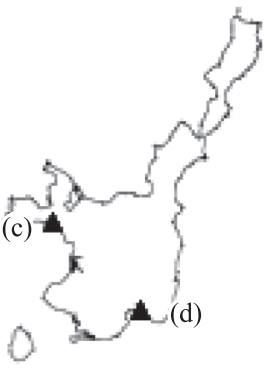

Ishigaki Island

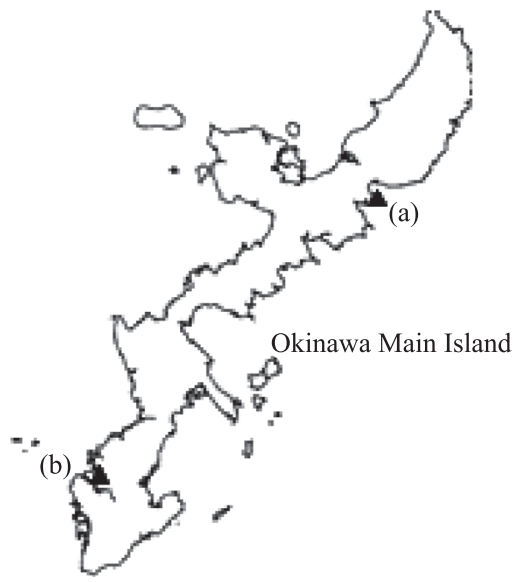

Fig. 1. Mangrove estuary sampling sites on the southwest islands of Japan. (a) Gesashi river, (b) Manko, (c) Nagura Gulf, (d) Miyara river, (e) Urauchi river, (f) Mare river, (g) Hinai river, (h) Shira river, (i) Maira river. In total, sediments were collected from 9 sites: 2 on Okinawa main island, 2 on Ishigaki Island, and 5 on Iriomote Island.

Table 1. Dominant mangrove species and meiobenthos at each survey site.

\begin{tabular}{llll}
\hline Map & \multicolumn{1}{c}{ Wetland } & \multicolumn{1}{c}{ Mangrove } & \multicolumn{1}{c}{ Meibenthos } \\
\hline (a) Gesashi River & K.o., B.g, R.s & \\
(b) Manko & K.o & \\
(c) Nagura Gulf & R.s & Polychaeta & \\
(d) Miyara River & K.o., B.g, R.s & & \\
(e) Urauchi River & R.s & Gammaridea, Turbellaria, \\
& & Ostracoda & \\
(f) Mare River & K.o., B.g, R.s & Oligochaeta & \\
(g) Hinai River & K.o., B.g, R.s & Nematoda & \\
(h) Shira River & R.s, S.a & & \\
(i) Maira River & R.s, & Oligochaeta & \\
\hline
\end{tabular}

Ko., Kandelia obovata; B.g., Bruguiera gymnorhiza; R.s., Rhizophora stylosa; S.a., Sonneratia alba.

for qualitative cellulase assay.

\section{Qualitative analysis of cellulase activity}

Meiobenthic animals were individually isolated from the sediments using forceps under a light microscope, homogenized with cold $20 \mu \mathrm{L}$ PBS and prepared for sodium dodecyl sulfate $7.5 \%$ polyacrylamide gel electrophoresis (SDS-PAGE) zymographic analysis. The length of the animals obtained ranged between 1 and $9 \mathrm{~mm}$. A similar method was used to prepare the feces of T. palustris from a midgut extract, adjusted to $1 \mathrm{mg} / \mathrm{mL}$, diluted 10 times with PBS and prepared for SDS-PAGE analysis.

Five volumes of sediment and 1 volume of $6 \times$ SDS sample buffer containing $0.6 \mathrm{M}$ Tris- $\mathrm{HCl}$ ( $\mathrm{pH} 6.8$ ), $60 \%$ glycerol, $6 \%$ SDS, and $0.06 \%$ bromophenol blue were homogenized (HandySonic UR-20P; TOMY SEIKO, Tokyo, Japan), incubated at $4^{\circ} \mathrm{C}$ for $2 \mathrm{~h}$ with shaking, centrifuged at $8,000 \times g$ for $5 \mathrm{~min}$ and the supernatant prepared for SDS-PAGE zymographic analysis.

Wood fragments of mangrove trees were removed from sediment using forceps. Approximately $0.5 \mathrm{~g}$ of mangrove residue, composed of wood fragments of mangrove trees or fallen leaves of Rhizophora stylosa, was rinsed thoroughly with tap water and diluted three times with distilled water, and then extracted using the same method as that used for the sediments. The protein concentration of the sediment extracts and mangrove residues was not detectable using the Bradford method.

Zymographic analysis of cellulose in the extracts prepared as above was performed using $7.5 \%$ or $10 \%$ SDSPAGE gels containing $0.1 \%$ carboxymethylcellulose. After electrophoresis, the gels were soaked in $10 \mathrm{mM}$ acetate buffer ( $\mathrm{pH}$ 5.5) containing $0.1 \%$ Triton $\mathrm{X}-100$ for $30 \mathrm{~min}$ to remove SDS, then transferred to $10 \mathrm{mM}$ acetate buffer $(\mathrm{pH}$ 5.5) and incubated at $37^{\circ} \mathrm{C}$ overnight. Cellulase activity was detected as an unstained band in the gel after staining with $0.1 \%$ Congo Red and destaining with $1 \mathrm{M} \mathrm{NaCl}$. 

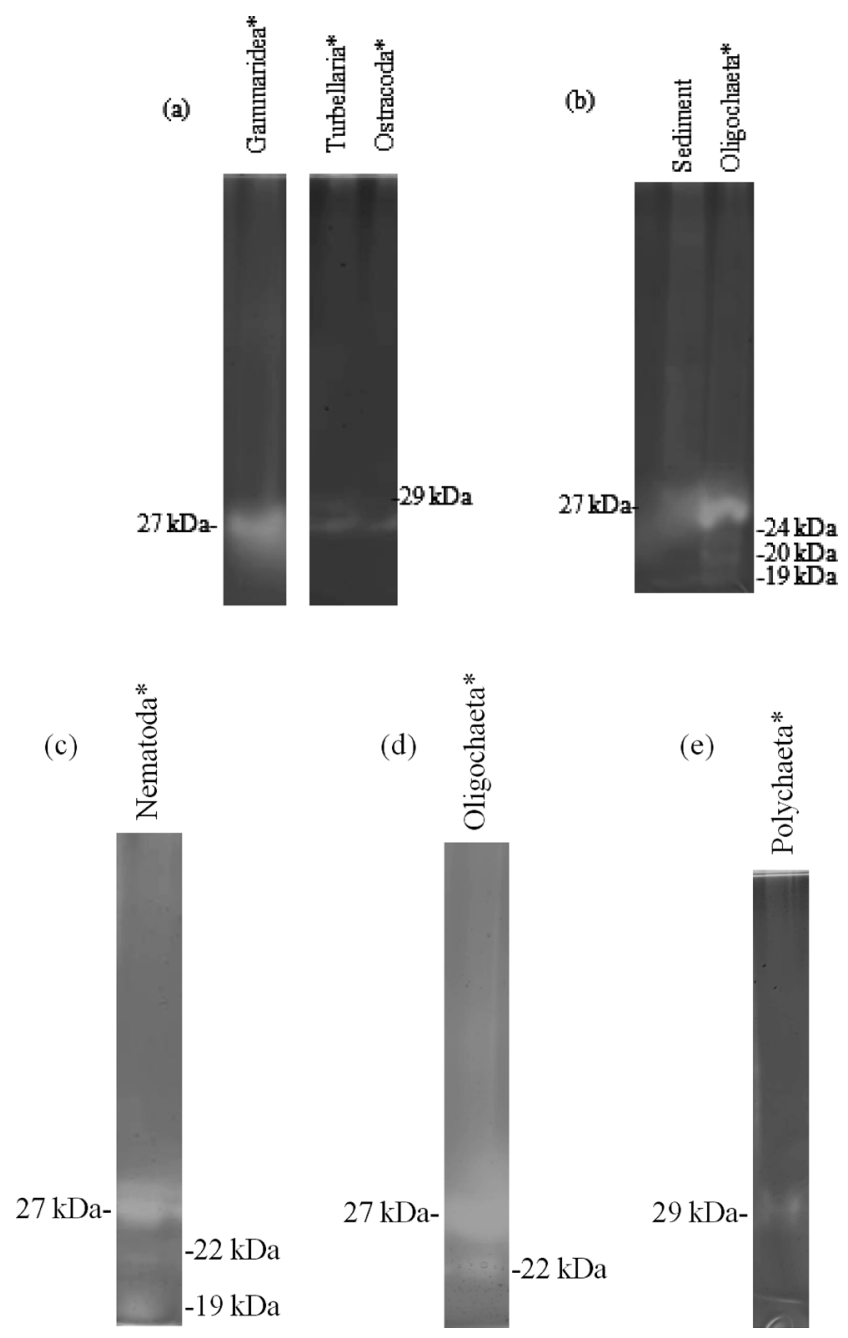

Fig. 2. Qualitative analysis of cellulase activity in samples collected during December 2010 using SDS-PAGE cellulose zymography. (a) Urauchi river: Lane 1, Gammaridea; lane 2, Turbellaria; lane 3, Ostracoda. (b) Mare river: Lane 1, sediment; lane 2, Oligochaeta. (c) Hinai river: lane 1, Nematoda. (d) Maira river: Lane 1, Oligochaeta. (e) Nagura Gulf: Lane 1, Polychaeta. Note that the active bands of each animal do not reflect the enzyme activity level correctly. The asterisks indicate that the animal belongs to meiobenthos.

\section{Results}

\section{Qualitative analysis of cellulases of meiobenthos and macrobenthos}

The cellulase activities of macro- and meiobenthic animals was measured to detect which animals were involved in reducing sugar-releasing activity in the mangroves. All animals from all nine sites exhibited active cellulase bands under SDS-PAGE zymographic analysis (Figs. 2, 3).

In 2010, it was noted that a large number of T. palustris in the Mare river are associated with sediment producing the most intensive cellulase activity seen in the zyomo-

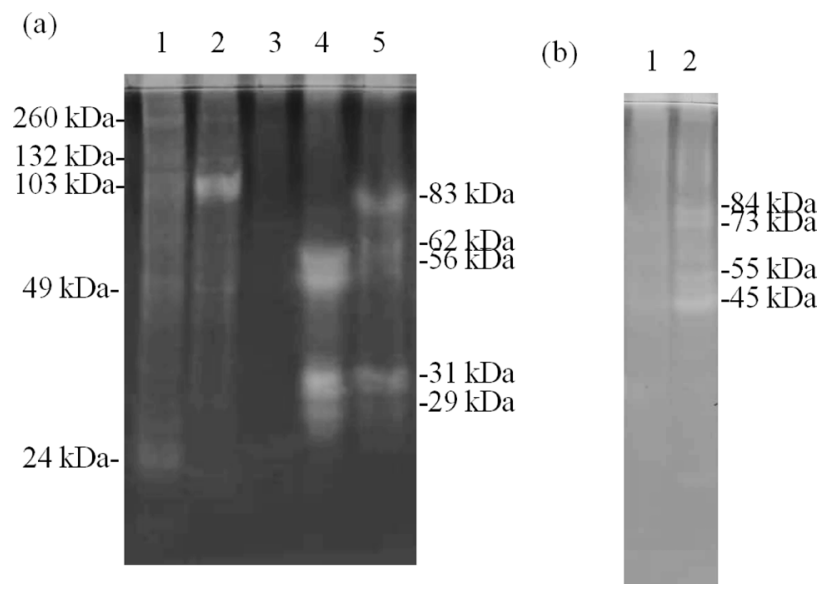

Fig. 3. Qualitative analysis of cellulase activity in samples collected during November 2011 from the Mare River and the Hinai River. (a) Mare River: 1, sediment; 2, mangrove chips; 3, fallen leaves of Rhizophora stylosa; 4, midgut gland of Terebralia palustris; 5, feces of Terebralia palustris. (b) Hinai River: 1, sediment; 2, mangrove chips. Electrophoresis was performed using $10 \%$ polyacrylamide gels.

graphic analysis among the all sampling sites examined. Sediments from the Mare and Hinai rivers were therefore collected once again in 2011 to investigate any connection between this phenomenon and cellulases secreted in the feces of T. palustris. Meiobenthos was absent from the sediments, possibly because of exceptionally heavy rainfall 3 days before collection. Interestingly, however, new active bands were detected at 24, 49, 103, 132, and $260 \mathrm{kDa}$ in these sediments (Fig. 3a, lane 1).

When we measured cellulase activities in the digestive organs of T. palustris, the midgut extract showed active bands at 29, 31, 49, and $56 \mathrm{kDa}$ (Fig. 3a, lane 4). To determine whether midgut cellulases are secreted via the feces, we measured the fecal cellulase activity of $T$. palustris and found 29-, 31-, 56-, 62-, and 83-kDa active bands from zymographic analysis (Fig. 3a, lane 5).

\section{Discussion}

The occurrence of cellulase activities in various meiobenthic animals from the mangrove ecosystem sediments of the southwestern Japanese Islands suggests that these animals contribute to the cellulase activity found in the sediment itself (Fig. 2; cf. Toyohara et al. 2012, Yamada \& Toyohara 2012). Interestingly, a common $27-\mathrm{kDa}$ active band differed from the results of previous studies (Toyohara et al. 2012, Yamada \& Toyohara 2012), suggesting a horizontal distribution of a gene encoding a $27-\mathrm{kDa}$ cellulase among meiobenthic animals in this region. This will require genetic identification of the $27-\mathrm{kDa}$ cellulase gene.

In the samples collected at the Mare river in 2010, the active cellulase band of sediment corresponded to that re- 
corded for oligochaetes (Fig. 2b). This result suggests that oligochaetes may play a major role in the cellulose degradation of the Mare river sediments. However, it is difficult to determine whether cellulase activity was derived from enzymes encoded by genes on the chromosomes of benthic animals such as the brackish water clam, or from the enzymes of symbiotic microorganisms such as the shipworm (Tanimura et al. 2013). Further molecular biological studies are required to investigate this. In 2011, additional sediment samples collected from the Mare and Hinai rivers exhibited higher activity compared to sediments collected in 2010, despite collection during the season: winter (Fig. 4); the active bands for these years were also different (Figs. 2 , and 3). Interestingly, meiobenthic animals were not detected in the sediments of the Mare and Hinai rivers in 2011, despite the assumption that they contributed to cellulose degradation based on the results obtained in 2010 . These findings suggest that the meiobenthos fauna probably changed between 2010 and 2011. Hence, long-term studies are required to evaluate the biochemical mechanisms of cellulose degradation in these mangrove sediments.

Cellulases bound to plant residues in sediments are assumed to be important in cellulose degradation (Yamada \& Toyohara 2012, Liu \& Toyohara 2012). Hence, we measured the cellulase activity of residues from mangrove trees, including wood fragments and leaves. Cellulase active bands at $49,103,132$, and $260 \mathrm{kDa}$ were commonly detected in both the sediment and wood fragments collected from the Mare river in 2011 (Fig. 3a, lane 1, 2). In addition, active bands at 45 and $73 \mathrm{kDa}$ were commonly observed in both the sediment and wood fragments collected from the Hinai river. These findings indicate that cellulase is adsorbed onto wood fragments in sediments, supporting the suggestions of previous studies (Yamada \& Toyohara 2012, Liu \& Toyohara 2012). Based on these results, mangrove fragments may bind cellulases preventing them from being washing out by water flow, which results in their functioning as bioreactors that efficiently degrade cellulose in sediments.

Large quantities of T. palustris inhabit the Mare river. In this study, a $31-\mathrm{kDa}$ cellulase active band was recorded in the midgut extract and feces of this species. Hence, cellulases may be secreted from the body via the feces. Immunological identification is required to validate this possibility.

It is considered that the meiobenthos and macrobenthos have important functions in the sediments of the mangrove estuaries of the Mare and Urauchi rivers, suggesting that these animals are involved in cellulose breakdown occurring in the southwestern Japanese Islands. However, cellulases secreted from micoorganisms including bacteria and fungi play important roles in the breakdown of mangrove fragments (Pointing et al. 1999, Gao et al. 2010). The possible implication of cellulases secreted in feces in addition to bacteria and fungi as a bioreactor in the breakdown pro- cess of cellulose in sediment was first demonstrated by Fig. 3 in the present paper. Liu \& Toyohara (2012) reported that cellulases bound to sediment function as a bioreactor in the rivers of the warm temperate region of Japan. Further studies are required to validate the hypothesis of a bioreactor breakdown system in sediment that is independent of benthic animals.

\section{Acknowledgements}

This study was partly supported by a Grant-in-Aid for scientific research from the Ministry of Education, Culture, Sports, Science, and Technology of Japan (no. 22255012), Asahi Glass Foundation and JSPS-NRCT Asian CORE Program granted to Tokyo University of Marine Science and Technology.

\section{References}

Alexander CG, Cutler RL, Yellowless D (1979) Studies on the composition and enzyme content of the crystalline style of Telescopium telescopium (L.) (Gastropoda). Comp Biochem Physiol B Biochem Mol Biol 64: 82-89.

Alongi DM (1987) Intertidal zonation and seasonality of meiobenthos in tropical mangrove estuaries. Mar Biol 95: 447-458.

Bachok Z, Mfilinge PL, Tsuchiya M (2003) The diet of the mud clam Geloina coaxans (Mollusca, Bivalvia) as indicated by fatty acid markers in a subtropical mangrove forest of Okinawa, Japan. J Exp Mar Biol Ecol 292: 187-197.

Bera-Maillet C, Devillard E, Cezette M, Jouany JP, Forano E (2005) Xylanases and carboxymethylcellulases of the rumen protozoa Polyplastron multivesiculatum, Eudiplodinium maggii and Entodinium sp. FEMS Microbiol Let 244: 149-156.

Bouillon S, Connolly RM, Lee SY (2008) Organic matter exchange and cycling in mangrove ecosystems: Recent insights from stable isotope studies. J Sea Res 59: 44-58.

Bouillon S, Koedam N, Baeyens W, Satyanarayana B (2004) Selectivity of subtidal benthic invertebrate communities for local microalgal production in an estuarine mangrove ecosystem during the post-monsoon period. J Sea Res 51: 133-144.

Bradford MM (1976) A rapid and sensitive method for the quantitation of microgram quantities of protein utilizing the principle of protein-dye binding. Anal Biochem 72: 248-254.

Chong VC (2007) Mangroves-fisheries linkages-the Malaysian perspective. Bull Mar Sci 80: 755-772.

Chong VC, Low CB, Ichikawa T (2001) Contribution of mangrove detritus to juvenile prawn nutrition: a dual stable isotope study in a Malaysian mangrove forest. Mar Biol 138: 77-86.

Chow CM, Yague E, Raguz S, Wood DA, Thurston CF (1994) The cel3 gene of Agaricus-bisporus codes for a modular cellulase and is transcriptionally regulated by the carbon source. Appl Environ Microbiol 60: 2779-2785.

Cosgrove DJ (2005) Growth of the plant cell wall. Nat Rev Mol Cell Biol 6: 850-861.

Gao ZM, Ruan LW, Chen XL, Zhang YZ, Xu X (2010) A novel salt-tolerant endo-beta-1,4-glucanase Cel5A in Vibrio sp G21 isolated from mangrove soil. Appl Microbiol Biotechnol 87: 
$1373-1382$

Hwang I H, Ouchi Y, Matsuto T (2007) Characteristics of leachate from pyrolysis residue of sewage sludge. Chemosphere 68: 1913-1919.

Joei WM, Gorge ED (2001) An Updated Classification of the Recent Crustacean. Natural History Museum of Los Angeles Country, Los Angeles, pp 1-124.

Kikuchi T, Shibuya H, Jones TJ (2005) Molecular and biochemical characterization of an endo- $\beta$-1,3-glucanase from the pinewood nematode Bursaphelenchus xylophilus acquired by horizontal gene transfer from bacteria. Biochem J 389: 117-125.

Liu W, Toyohara H (2012) Sediment-complex-binding cellulose breakdown in wetlands of rivers. Fish Sci 78: 661-665.

Loneragan NR, Bunn SE, Kellaway DM (1997) Are mangroves and seagrasses sources of organic carbon for penaeid prawns in a tropical Australian estuary? A multiple stable-isotope study. Mar Biol 130: 289-300.

Meziane T, Tsuchiya M (2000) Fatty acids as tracers of organic matter in the sediment and food web of a mangrove/intertidal flat ecosystem, Okinawa, Japan. Mar Ecol Prog Ser 200: 4957.

Niiyama T, Hanamura Y, Tanaka K, Toyohara H (2012) Occurrence of cellulase activities in mangrove estuarine mysids and Acetes shrimps. JIRCUS Work Rep 75: 35-40.

Niiyama T, Toyohara H (2011) Widespread distribution of cellulase and hemicellulase activities among aquatic invertebrates. Fish Sci 77: 649-655.

Niiyama T, Toyohara H, Tanaka K (2012) Cellulase activity in blood cockle (Anadara granosa) in the Matang Mangrove Forest Reserve, Malaysia. Jpn Agr Res Q in press.

Nishida Y, Suzuki K, Kumagai Y, Tanaka H, Inoue A, Ojima T (2007) Isolation and primary structure of a cellulase from the Japanese sea urchin Strongylocentrotus nudus. Biochimie 89: 1002-1011.

Olson DG, Tripathi SA, Giannone RJ, Lo J, Caiazza NC, Hogsett DA, Hettich RL, Guss AM, Dubrovsky G, Lynd LR (2010) Deletion of the Cel48S cellulase from Clostridium thermocellum. Proc Natl Acad Sci USA 107: 17727-17732.

Pointing SB, Buswell JA, Jones EBG, Vrijmoed LLP (1999) Extracellular cellulolytic enzyme profiles of five lignicolous mangrove fungi. Mycol Res 103: 696-700

Robert PH, Hjalmar T (1988) Introduction to the Study of Meiofauna. Smithsonian Institution Press, Washington, D.C, pp
243-354.

Ronsness PA (1968) Cellulolytic enzymes during morphogenesis in Dictyostelium discoideum. J Bacterial 96: 639-645.

Sakamoto K, Touhata K, Yamashita M, Kasai A, Toyohara H (2007) Cellulose digestion by common Japanese freshwater clam Corbicula japonica. Fish Sci 73: 675-683.

Suzuki K, Ojima T, Nishita K (2003) Purification and cDNA cloning of a cellulase from abalone Haliotis discus hannai. Eur J Biochem 270: 771-778.

Smant G, Stokkermans PWGJ, Yan Y, Boer de MJ, Baum JT, Wang XH, Hussey RS, Gommers FJ, Henrissat B, Davis EL, Helder J, Schots A, Bakker J (1998) Endogenous cellulases in animals: Isolation of $\beta$-1,4-endoglucanase genes from two species of plant-parasitic cyst nematodes. Proc Natl Acad Sci USA 95: 4905-4911.

Takeshita Y, Noguchi H (1974) Mangroves grown at Minami-Izu, Japan. J Jpn Soc Bot Gard 9: 7-14.

Tanimura A, Liu W, Yamada K, Kishida T, Toyohara H (2013) Animal cellulases with a focus on aquatic invertebrates. Fish Sci 79: 1-13

Toyohara H, Park Y, Tsuchiya K, Liu W (2012) Cellulase activity in meiobenthos in wetlands. Fish Sci 78: 133-137.

Trinci APJ, Davies DR, Gull K, Lawrence MI, Nielsen BB, Rickers A, Theodorou MK (1994) Anaerobic fungi in herbivorous animals. Mycol Res 98:129-152.

Vries RP, Visser J (2001) Aspergillus enzymes involved in breakdown of plant cell wall polysaccharides. Microbiol Rev 65: 497-522.

Wakushima S, Kuraishi S, Sakurai N (1994) Soil salinity and pH in Japanese mangrove forests and growth of cultivated mangrove plants in different soil conditions. J Plant Res 107: 3946.

Watanabe H, Noda H, Tokuda G, Lo N (1998) A cellulase gene of termite origin. Nature 394:330-331.

Watanabe H, Tokuda G (2010) Cellulolytic systems in insects. Annu Rev Entomol 55: 609-632.

Xu BZ, Janson JC, Sellos D (2001) Cloning and sequencing of a molluscan endo-beta-1,4-glucanase gene from the blue mussel, Mytilus edulis. Eur J Biochem 268: 3718-3727.

Yamada K, Toyohara H (2012) Function of meiobenthos and microorganisms in cellulose breakdown in sediments of wetlands with different origins in Hokkaido. Fish Sci 78: 699-706. 